\title{
Approaches to Price Formation in FinANCIALISED COMMODITY MARKETS
}

\author{
Sophie van Huellen*
}

\begin{abstract}
A recent debate about the financialisation of commodity markets has stimulated the development of new approaches to price formation which incorporate index traders as a new trader category. I survey these new approaches by retracing their emergence to traditional price formation models and show that they arise from a synthesis between commodity arbitrage pricing and behavioural pricing theories in the tradition of Keynesian inspired hedging pressure models. Based on these insights, I derive testable hypotheses and provide guidance for a growing literature that seeks to empirically evaluate the effects of index traders on price discovery in commodity futures markets.
\end{abstract}

Keywords: commodity prices; commodity futures; financialisation; index investment; speculation

JEL: D84, G13, Q02

\section{Data Availability}

The data that support the findings of this study are available from the corresponding author upon reasonable request.

\section{Acknowledgment}

The research was supported financially by the German National Academic Foundation and Andrey Kuleshov and Elena Ivashentseva. I am grateful to Prof Machiko Nissanke, Prof Raphael Kaplinsky and Dr Joerg Mayer for their detailed comments on an earlier version of this paper. I also want to thank three anonymous referees for their constructive feedback and comments.

*SOAS University of London, Thornhaugh Street, Russell Square, London WC1H 0XG. Email: sv8@soas.ac.uk. Tel.: +44 (0) 2078984543. 


\section{Introduction}

Since the early 2000s, commodity futures markets have attracted a large influx of liquidity due to their favourable diversification properties (Erb and Harvey, 2006; Gorton and Rouwenhorst, 2006) and their satisfactory performance as an alternative asset class in a low interest environment (Mayer, 2012; Basu and Gavin, 2011). Investors can achieve exposure through passive instruments such as commodity indices, whereby investments are allocated to commodity futures markets in accordance with the composition of the index that investors seek to replicate. Index traders are long-only, do not attempt to arbitrage the market, their trading behaviour is largely detached from the respective market's fundamentals and positions are correlated with global liquidity cycles (Nissanke, 2012; Mayer, 2012; Brunetti and Reiffen, 2014). Due to their unique investment behaviour, index traders are suspected to cause price levels, volatilities and co-movements beyond what could be explained by market fundamentals (Masters, 2008).

This so called 'financialisation of commodity markets', e.g. see Irwin and Sanders (2012) and Henderson et al. (2015), has stimulated the development of new approaches to price formation in commodity futures markets which incorporate the presence of index traders. Historically, price formation models for commodity futures markets emerged from two interlinked traditions: arbitrage pricing and behavioural pricing models. Arbitrage pricing models derive intertemporal price relations between spot and futures markets (or between futures with different maturity dates) under the law of one price. Behavioural pricing models derive prices from clearing conditions in markets in which some agents may not be rational optimisers or may face market frictions. Both traditions consider heterogenous agents by distinguishing between hedgers and speculators in the arbitrage pricing literature and informed and uninformed speculators in the behavioural pricing literature. With the arrival of index traders, 
a new generation of price formation models emerged which provides crucial insights into the implications of index trading for price discovery and risk management.

The prime objective of this paper is to provide guidance for a growing empirical literature that investigates financialisation effects by reviewing recently developed theoretical models of price formation in financialised commodity markets and deriving testable hypotheses from this review. I focus on storable primary commodities and their futures markets. ${ }^{1}$ I hence largely exclude an important set of literature that investigates price formation in commodity spot and storage markets - see Gouel (2012) for a comprehensive review -, unless this literature makes direct reference to implications of speculative trading in futures markets for spot and storage markets.

Arbitrage pricing theories are reviewed in Section 2 and behavioural pricing theories are reviewed in Section 3. I then review new approaches to price formation in financialised commodity markets in Section 4. I show that these new approaches emerge from a synthesis between arbitrage and behavioural pricing theories, following closely Keynesian inspired hedging pressure theories. In section 5, I derive testable hypotheses from the theoretical approaches reviewed in Section 4 as guidance for a growing empirical literature on the financialisation of commodity markets. I further conduct a meta-analysis of the empirical literature to identify adequate empirical strategies for the testing of the derived hypotheses. In Section 6, I conclude with suggestions for future research.

\section{Arbitrage Pricing Models}

A no-arbitrage condition between commodity futures and their underlying spot prices builds the foundation for different theories of price formation in commodity markets. Prices are

\footnotetext{
${ }^{1}$ Caution must be exercised when extending the arguments presented here to commodities such as energy with limited storability and precious metals that act as store of wealth.
} 
assumed to be driven by supply and demand conditions in the spot markets, while the possibility of arbitrage ensures alignment of the futures price to its underlying spot price. The no-arbitrage condition can be summarised as in Eq. (1). ${ }^{2} F_{t, T}$ is the price of a futures contract at time $t$ that matures at time $T, S_{t}$ is the cash price, $r$ and $w$ are cost of capital and cost of storage $^{3}$ prevailing at date $t$ for maturity $T$ and $\tau=T-t$ is the time to maturity.

$$
F_{t, T}=S_{t} e^{(r+w) \tau}
$$

At maturity $\tau \rightarrow 0$ so that $F_{T, T}=S_{T}$ and the market basis $B_{T} \equiv S_{T}-F_{T, T}=0$. However, futures and spot prices do not necessarily comply with Eq. (1) empirically. Particularly, a situation in which the futures contract trades below the spot price (backwardation) has received attention since futures contracts are bound to trade above the spot price (contango), as $(r+w) \tau \geq 0$ in Eq. (1). The theory of convenience yield, ascribed to Kaldor (1939), Working (1949) and Brennan (1958), and the theory of risk premium, advanced by Keynes (1930) and Hicks (1939), offer two distinct, although complementary, explanations for backwardation.

\subsection{Theory of Storage}

The theory of storage explains backwardation with the distinct economic properties of the physical good compared to its derivative. Kaldor (1939) introduces a convenience yield, $\varphi=$ $\varphi(\mathrm{I})$, which is acquired from owning a commodity and is inversely related to speculative stocks, $I$, that is, stocks beyond what is required for normal business.

$$
F_{t, T}=S_{t} e^{(r+w-\varphi) \tau}
$$

\footnotetext{
${ }^{2}$ Eq. (1) describes the relationship between a forward contract at time $t$ for maturity $T$ and its underlying spot price. However, under the assumptions of deterministic interest rates and no credit risk, futures and forward contracts are equivalent and Eq. (1) is equally valid for a futures contract with maturity $T$ (Geman, 2005 p.44).

${ }^{3}$ For simplicity, $r$ and $w$ are assumed to be constant over the period $\tau$.
} 
As evident from Eq. (2), the extent of backwardation (or positive market basis) does not have a limit, but a contango (or negative market basis) has its maximum in the carry $\operatorname{cost}(r+w) \tau$ with $\varphi=0$ (Lautier, 2005).

The convenience yield found multiple interpretations in the literature. Kaldor (1939) originally introduced the yield as the inverse of Keynes's own rate of interest. Later authors, such as Brennan (1958), Pindyck (2001), Bozic and Fortenbery (2011) and Pirrong (2011) proposed a utility-based explanation for the convenience yield. The convenience yield accrues to the owner of inventory due to the opportunity gained from taking advantage of an unexpected increase in demand. Despite the different opinions on what constitutes the convenience yield, authors agree on an inverse relationship between the yield and storage. Pindyck (2001) formalises this relationship and shows that if a commodity is storable, the equilibrium in the physical market is not only governed by production and consumption, but also by changes in inventories, which enters the futures price through the convenience yield.

The triangular relationship between spot, inventory and futures markets brings forth complex feedback mechanisms. Positive price trends in volatile markets can be intensified through inventory hoarding, either because inventories serve as physical options (Deaton and Laroque 1992; Singleton 2014; Guo and Leung 2017), or because they are accumulated for precautionary reasons (Pindyck 2001; Bozic and Fortenbery 2011). While various models take these complex feedback mechanisms into consideration - see Gouel (2012) - many of these models remain incomplete because futures markets are modelled as a reflection of dynamics in spot and inventory markets; e.g. Pindyck (2001). Conceptualised this way, futures markets serve an information function by revealing storage availability and agents' preferences through the convenience yield, but do not serve a price discovery function. 


\subsection{Theory of risk premium}

A second, arbitrage-based approach, assumes that prices should be subject to a risk premium since non-commercial speculators demand a premium for taking on hedgers' risk (Keynes, 1930; Hicks, 1939, p. 147-8). As the number of short hedgers does not match the number of long hedgers at any point in time, speculators ${ }^{4}$ are invaluable in providing liquidity (Working, 1960). Hedgers are not exposed to any price risk after entering the hedging position, while speculators take on risk exposure and therefore provide an insurance service to hedgers. Depending on the relative weight of short and long hedgers in the market, futures markets are in contango or in backwardation.

The original risk premium theory is based on an excess demand framework and was critiqued by Fama and French (1987) and others for being incompatible with general equilibrium theory. Two strands of theories, which seek to make Keynes's risk premium approach coherent within a neoclassical framework, have evolved: (1) theories of asset pricing which assign a risk premium to (systematic) risk, e.g. Dusak (1973); and (2) theories of hedging pressure which incorporate market imperfections, like transaction costs, into multi-period pricing models, e.g. Hirshleifer (1988; 1990).

Kaldor (1939) links the risk premium to the uncertain expectations of future prices. The degree of uncertainty depends on the own price variance, $\sigma_{i}^{2}$, and the difference between the expected spot price and current spot price is determined by net-carry cost and a risk premium, $\pi=$ $\pi\left(\sigma_{i}^{2}\right)$ :

$$
E_{t}\left[S_{T}\right]=S_{t} e^{(r+w-\varphi+\pi) \tau}
$$

\footnotetext{
${ }^{4}$ Following Working (1960), the term 'speculator' refers to any trader whose primary business does not involve trading the physical commodity.
} 
Substituting Eq. (2) into Eq. (3), it is shown that the forward price, $F_{t, T}$, falls short of the expected spot price by the risk premium and the forward price becomes a biased estimator of the expected future spot price.

$$
F_{t, T}=E_{t}\left[S_{T}\right] e^{-\pi \tau}
$$

Departing from Kaldor (1939), Dusak (1973) links the risk premium to systematic risk instead of idiosyncratic risk. She is the first to apply a capital asset-pricing model (CAPM) to the commodity futures market and to show that the expected excess return on commodity $i$ over one period, $E_{t}\left[\tilde{R}_{i}\right]-r_{t}$, with $r_{t}$ being the risk-free rate, is equal to the expected excess market return, $E_{t}\left[\tilde{R}_{m}\right]-r_{t}$, multiplied by the market beta defined as $\beta=\frac{\operatorname{Cov}\left(\tilde{R}_{m t}, \tilde{R}_{i t}\right)}{\sigma^{2}\left(\tilde{R}_{m t}\right)}$.

$$
\left(E_{t}\left[\tilde{R}_{i}\right]-r_{t}\right)=\beta\left(E_{t}\left[\tilde{R}_{m}\right]-r_{t}\right)
$$

After substituting $E_{t}\left[\tilde{R}_{i}\right]-r_{t}=\left\{E_{t}\left[S_{t+1}\right]-S_{t}\left(1+r_{t}\right)\right\} / S_{t}$ and interpreting $S_{t}\left(1+r_{t}\right)$ as the current futures price $F_{t, t+1}$ for delivery and payment one period ahead, Eq. (5) yields $F_{t, t+1}=$ $E_{t}\left[S_{t+1}\right]-S_{t} \pi_{t}^{\prime}$ with:

$$
\pi_{t}^{\prime}=\beta\left(E_{t}\left[\tilde{R}_{m}\right]-r_{t}\right)
$$

For a multiperiod case, this becomes $F_{t, T}=E_{t}\left[S_{T}\right]-S_{t} \pi_{t}^{\prime} \tau$, which is a linear version of Eq. (4) with time varying $\pi$; see Geman (2005, p.37).

Alongside theories which link the risk premium to own and cross-price variation, hedging pressure theories developed, which are, arguably, closer to Keynes's original idea. Hedging pressure models derive the premium as a function of demand for hedging positions under the assumption that the supply of contrarians to hedging positions is not perfectly elastic due to market frictions (Hirshleifer, 1988; 1990; Chang, 1985; Bessembinder, 1992). 
Hirshleifer (1988) distinguishes between two trader types - producers (hedgers) and outside investors (speculators) - in a two-period model and assumes that the latter trader type incurs transaction costs due to fixed set-up costs or effective informational barriers. In a later model, he adds fixed set-up costs for long hedgers and assumes risk-averse speculators instead and arrives at similar conclusions (Hirshleifer, 1990). Hirshleifer $(1988 ; 1990)$ shows that under these assumptions a trader's optimal choice of positions depends on the size of the transaction cost $k$ and the trader's risk perception so that the risk premium entails a systematic risk component as in Dusak (1973), which depends on the market beta - the first component of Eq. (7) - and a residual risk component, which rises in absolute terms with the square root of the transaction cost - the second component of Eq. (7).

$$
\pi_{t}^{\prime \prime}=\beta\left(E_{t}\left[\tilde{R}_{m}\right]-r_{t}\right) \pm \sigma_{i} \sqrt{2 \alpha k\left(1-\rho^{2}\right)}
$$

As before, $\sigma_{i}$ is the standard deviation of $\tilde{R}_{i}, \alpha$ is the coefficient of absolute risk aversion, and $\rho=\operatorname{Cor}\left(\tilde{R}_{m t}, \tilde{R}_{i t}\right)$. The second component in Eq. (7) can be positive and negative, depending on whether there are more short hedgers or long hedgers in the market.

Table 1. Summary Table Arbitrage Pricing Models Based on Eq. (1) - (7)

\begin{tabular}{llll}
\hline No-arbitrage & Convenience yield & Risk premium & \\
\hline & & Idiosyncratic \\
& & $\pi_{t}=\pi_{t}\left(\sigma_{i}^{2}\right)$ \\
& & Systematic \\
$F_{t, T}=S_{t} e^{(r+w) \tau}$ & $F_{t, T}=S_{t} e^{(r+w-\varphi) \tau}$ & $F_{t, T}=E_{t}\left[S_{T}\right] e^{-\pi \tau}$ & $\pi_{t}^{\prime}=\beta\left(E_{t}\left[\tilde{R}_{m}\right]-r_{t}\right)$ \\
& & Hedging pressure \\
& & $\pi_{t}^{\prime \prime}=\pi_{t}^{\prime}+\pi_{t}^{*}$ \\
& & with $\pi_{t}^{*}= \pm \sigma_{i} \sqrt{2 \alpha k\left(1-\rho^{2}\right)}$ \\
\hline
\end{tabular}

Hedging pressure theories are related to more general price pressure theories which are based on the assumptions of risk aversion and transaction costs; e.g. see Harris and Gurel (1986) and Shleifer (1986). Since these models combine arbitrage pricing with a microstructure for trader 
behaviour, they form a synthesis of arbitrage and behavioural pricing models. Table 1 summarises the different theories derived from the simple no-arbitrage condition.

\section{Behavioural Pricing Models}

Behavioural pricing models are based on a different kind of arbitrage relation than the previously reviewed storage models and are more general in that they apply to multiple asset classes alongside commodities. ${ }^{5}$ The behavioural pricing literature relies on fundamental arbitrage where arbitrage opportunities arise if prices deviate from their fundamental value, while previously reviewed theories rely on spatial arbitrage where arbitrage opportunities arise if $\operatorname{spot}^{6}$ and futures prices deviate. By implication, spatial arbitrage enforces a close relationship between two related markets but does not necessarily link an asset to its fundamental value. Fundamental arbitrage corrects for an over- or under-valuation of an asset, but not for a misspecification in relative prices.

The concept of fundamental arbitrage is related to the efficient market hypothesis (EMH), first formulated by Fama (1965) in its weak form. According to this hypothesis, commodity futures prices are determined by traders' consensus expectations regarding the market's future fundamental value. Each trader $j$ is assumed to base her trading decision on a subset of the total information set of market fundamentals $\left[\Omega_{j, t} \in \bar{\Omega}\right]$. Consequently, each position taken by a trader will add to the market information density. With perfect foresight, the probability of the future price of the commodity would be certain, so that: $P\left(S_{T} \mid \bar{\Omega}\right)=1$, and hence, $F_{t, T}=$ $E_{t}\left[S_{T} \mid \bar{\Omega}\right]=S_{T}$

\footnotetext{
${ }^{5}$ As discussed previously, arbitrage pricing or storage models intersect with the behavioural pricing literature in the risk premium approaches.

${ }^{6}$ Or any other close substitute to futures.
} 
The proposed alignment of a market with its fundamentals relies on a row of conditions. Key market participants must evaluate assets regarding fundamentals only, base their actions on publicly available information or their own private sources and do so independently of each other. If these conditions are met, traders' price expectations are identically and independently distributed around the fundamental value of the commodity and the more traders enter the market, the closer the futures price approaches its fundamental value (Carter, 1991). Further, sophisticated arbitrageurs immediately identify and take advantage of any price deviation induced by misguided 'noise' traders if unconstrained in their resources. These assumptions have been challenged on epistemological grounds by the behavioural finance and market microstructure literature and on ontological grounds by the Post-Keynesian literature.

\subsection{Bounded Rationality and Rational Herding}

Bounded rationality theories question the capabilities of individuals to act fully rational, while rational herding theories acknowledge that if the degree of uncertainty is measurable but information gathering is costly, traders are incentivised to follow other traders instead of their own information; see Shleifer (2000) for an overview. Both theories allow a set of different trader behaviours, including arbitrage as well as trend following, chartism and other technical trading strategies. Under the assumption of heterogeneity in trading motives and strategies, not every investor's position necessarily adds to the overall information set regarding market fundamentals (Hayes, 2006; Adam and Marcet, 2010, 2011).

The bounded rationality perspective is closely linked to behavioural finance, which moves away from the assumption of fully rational agents and takes a more eclectic approach to understanding agents' behaviour. Theories are informed by cognitive science, human psychology, evolutionary biology and sociology (Baddeley, 2010). The term bounded rationality was originally coined by Simon (1955), who argues that individuals are unable to 
act as assumed in the neoclassical optimisation process. Earlier studies in the field understand noise traders as non-rational insofar as their demand for risky assets is affected by beliefs and sentiments. Traders tend to become overly optimistic or pessimistic (Shleifer and Summers, 1990) and tend to employ common heuristics to assess complex probabilities (De Long et al., 1990; Hirschleifer, 2001). Consequently, markets frequently overreact or underreact to information as optimising agents employ trial-and-error strategies in an evolutionary manner (De Grauwe and Grimaldi, 2006; Adam and Marcet, 2010, 2011; Lo, 2012). With increasing uncertainty, even rational traders switch to trial-and-error strategies as they become more profitable. Such behaviour of market participants results in multiple equilibria and lowfrequency boom and bust cycles as investment strategies undergo cycles of profit and loss.

The rational herding perspective introduces market frictions and is closely associated with market microstructure theories, which take the institutional environment and its links to the price formation process into consideration (O'Hara, 1997). Rational herding can occur in the presence of market friction such as payoff externalities, principal-agent problems, and informational learning (Devenow and Welch, 1996). The literature around payoff externalities focuses on second- and third-generation currency crisis models and the occurrence of bank runs (Krugman, 1979; Obstfeld, 1986; Jeanne, 2000). Principal-agent problems arise over perverse incentives so that, for instance, asset managers prefer to 'hide in the herd' (Devenow and Welch, 1996; Scharfstein and Stein, 1990). The third friction arises when partially informed agents discard their own information in the light of information inferred from the observed actions of other agents due to known information asymmetries and costs to information gathering (Welch, 1992; Banerjee, 1992; Bikhchandani et al., 1992; McAleer and Radalj, 2013).

Both strands of literature, bounded rationality and rational herding theories, divide financial market participants into two categories: informed fundamental arbitrage traders and 
uninformed systematic noise traders. Both theories conclude that noise trader positions can be strongly correlated and lead to aggregate demand shifts, which impact prices if the noise traders' weight in the market is large enough. If limits to fundamental arbitrage exist due to the presence of 'noise trader risk' (De Long et al., 1990), transaction costs such as margin calls (Shleifer and Summers, 1990) or agency problems if arbitrage traders trade on behalf of clients (Shleifer und Vishny, 1997), fundamental arbitrage might fail to align consensus expectations across spot and futures markets.

\subsection{Post-Keynesian Fundamental Uncertainty}

Post-Keynesian authors reject the assumption of ergodicity, so that 'true' or unmeasurable uncertainty arises (Rosser Jr., 2001). An uncertain future is unknowable and cannot be predicted based on past and present observations as the system is permanently changed so that the past is not representative of the future, resulting in fundamental uncertainty (Lawson, 1985; Dunn, 2001; Davidson, 2002, p. 47). Therefore, a commodity's expected fundamental value cannot be quantified by market practitioners (Bernstein, 1999). If market practitioners are aware of the unknowability of the future, portfolio protection through diversification against changes in financial markets is an important activity (Davidson, 2002, p. 188). So, too, is speculation over the psychological state of other market practitioners (Carabelli, 2002).

However, the premise of non-ergodicity does not negate the existence of knowledge per se. Lawson (1985) argues that knowledge about something, understood as knowledge about the probability proposition of something, is possible. He distinguishes between cases where the probability is unknown due to lack of skills, close to the bounded rationality literature, and cases where the probability is immeasurable or indeterminate. Only in the latter case does true uncertainty exist. For Lawson (1985), traders are heterogeneous in their trading strategies, since trading motives are conditioned on knowledge and the interpretation of knowledge that is 
obtained by each individual trader through practice. Similarly, Bibow et al. (2005) refer to Beckert (1996) and argue that reliance on peoples' 'social devices' makes action more predictable. Mimicking then arises from the attempt to conform to the majority.

For bounded rationality, rational herding and fundamental uncertainty, the past only offers limited guidance for predicting future events, because the past cannot be fully comprehended, the comprehension of the past is costly, or the past is substantially different from the future. In all three settings, optimisation is impossible or greatly limited so that agents return to conventions violating rationality assumptions of the EMH.

\section{Price Formation in Financialised Commodity Markets}

With the arrival of index traders in commodity futures markets the binary divisions between hedgers and liquidity-providing speculators or informed and uninformed speculators become insufficient as index traders appear to be of an altogether different kind. With reference to the previously reviewed literature, studies discussing potential implications of index traders for price discovery and hedging effectiveness in commodity futures markets suggest a fourfold division of trader types: hedgers, informed speculators, uninformed speculators and index traders; e.g. see Nissanke (2012) and Mayer (2012).

The four trader types arise from different combinations of the contrasting categories informed and uninformed traders and active and passive traders as summarised in Table 2. Active traders are those who trade based on commodity specific information signals, either information signals about market fundamentals or information extracted from price signals by use of statistical patterns. The latter are referred to as uninformed traders as they attempt to infer information from price signals and do not bring new information into the price discovery process. Passive traders are those who do not take commodity specific information into 
consideration when making trading decisions but rather base their trading strategies on global liquidity cycles, such as index traders.

Table 2. Trader Categories Under Different Theories

\begin{tabular}{|c|c|c|c|c|c|}
\hline & & & $\begin{array}{c}\text { Arbitrage } \\
\text { Pricing Theories }\end{array}$ & $\begin{array}{c}\text { Behavioural } \\
\text { Pricing Theories }\end{array}$ & $\begin{array}{c}\text { Financialisation } \\
\text { Theories }\end{array}$ \\
\hline Active & Informed & Hedgers/Arbitrage & $\mathrm{X}$ & $(\mathrm{X})$ & $\mathrm{X}$ \\
\hline Active & Informed & Speculators/Arbitrage & $\mathrm{X}$ & $X$ & $\mathrm{X}$ \\
\hline Active & Uninformed & Speculators/Chartists & & $\mathrm{X}$ & $(\mathrm{X})$ \\
\hline Passive & Uninformed & Index investors & & & $\mathrm{X}$ \\
\hline
\end{tabular}

Indices are relatively novel investment instruments for commodities but have a long history in stock markets where index investments were empirically linked to substantial and relatively permanent increases of stock returns (Harris and Gurel, 1986; Shleifer, 1986), a reduction in the information content of stock markets resulting in an increase in price volatility (Grossman, 1988; Brennan and Schwartz, 1989), and an increase in co-movement across indexed stocks (Greenwood, 2005; Barberis et al., 2005; Basak and Pavlova, 2013).

In the following, I focus on approaches to price formation that explicitly account for the presence of index traders as passive investors in commodity futures markets. To the best of my knowledge, only three pricing models, compared in Table 3, fall into this category: Basak and Pavlova (2016), Brunetti and Reiffen (2014) and Hamilton and Wu (2014; 2015). All three models build on a synthesis of arbitrage and behavioural pricing models, with reference to hedging and price pressure theories; although the synthesis remains incomplete in some important ways as I will discuss in the following.

Basak and Pavlova (2016) suggest a dual trader division in which they contrast between informed speculators and institutional investors that hold commodity indices as part of their portfolio. They do not make explicit reference to the hedging pressure literature, but to price pressure models in general and the literature on index trading in stock markets. Their model 
predicts that index investment leads to co-movement between commodities included in the same index, increased price volatilities and increased price levels. Based on the competitive storage model by Deaton and Laroque (1992), Basak and Pavlova (2016) show that if institutional investors are also shareholders of storage firms, inventories are withheld, which, in turn, leads to higher spot prices.

Table 3. Summary of Price Formation Models that Account for Index Investment

\begin{tabular}{|c|c|c|c|}
\hline & Basak and Pavlova (2016) & Brunetti and Reiffen (2014) & Hamilton and Wu (2014) \\
\hline Hedgers & NA & $\begin{array}{l}\text { Utility function: } \\
u_{H}\left(W_{H T}\right)=A- \\
\exp \left(-\alpha W_{T}\right)\end{array}$ & Exogenous: NA \\
\hline $\begin{array}{l}\text { Informed } \\
\text { speculators }\end{array}$ & $\begin{array}{l}\text { Utility function: } \\
u_{S}\left(W_{S T}\right)=\log \left(W_{S T}\right)\end{array}$ & $\begin{array}{l}\text { Utility function: } \\
u_{S}\left(W_{S T}\right)=A- \\
\exp \left(-\alpha W_{T}\right)\end{array}$ & $\begin{array}{l}\text { Utility function: } \\
u_{S}\left(W_{S T}\right)=E_{t}\left[W_{T}\right]- \\
\alpha \operatorname{Var}_{t}\left(W_{T}\right) .\end{array}$ \\
\hline $\begin{array}{l}\text { Index } \\
\text { investors }\end{array}$ & $\begin{array}{l}\text { Utility function: } \\
u_{I}\left(W_{I T}\right)=(a+ \\
\left.b \psi_{T}\right) \log \left(W_{I T}\right), a, b>0 \\
\psi_{T}=\prod_{i=1}^{L} F_{i T}^{1 / L}, L \leq K .\end{array}$ & $\begin{array}{l}\text { Exogenous: } \\
I_{i} \cdot(\text { positions in contract } \mathrm{i}) \\
N_{H} X_{H}^{i}+N_{S} X_{S}^{i}=-I_{i} .\end{array}$ & $\begin{array}{l}\text { Exogenous: } \\
I_{i} \cdot(\text { positions in contract } \mathrm{i})\end{array}$ \\
\hline $\begin{array}{l}\text { Investment } \\
\text { choices }\end{array}$ & $\begin{array}{l}\text { Stock market, bond market, } \\
\text { commodity market. } \\
W_{n T}=\sum r_{t} Q_{n}+\sum f_{t} X_{n} \\
n \in\{S, I\}\end{array}$ & $\begin{array}{l}\text { Two consecutive futures } \\
\text { contracts traded in the same } \\
\text { market. } \\
W_{n T}=W_{0}+\sum f_{t} X_{n}+f_{T} C_{n} \\
\quad n \in\{S, H\}, C_{S}=0, C_{H}=C\end{array}$ & $\begin{array}{l}\text { Stock market, bond market, } \\
\text { commodity market. } \\
W_{S T}=\sum r_{t} Q_{S}+\sum f_{t} X_{S}\end{array}$ \\
\hline Implications & $\begin{array}{l}\text { Excess co-movement, } \\
\text { volatility, price level. }\end{array}$ & $\begin{array}{l}\text { Excess spread, co-movement, } \\
\text { price level. }\end{array}$ & Excess spread, price level. \\
\hline $\begin{array}{l}\text { Extension } \\
\text { spot prices }\end{array}$ & $\begin{array}{l}\text { Inventory hoarding resulting } \\
\text { in higher spot prices. }\end{array}$ & NA & NA \\
\hline \multicolumn{4}{|c|}{$\begin{array}{l}\text { Notes: } T \text { is the date of consumption, } t \text { is the current date, } u \text { is utility, } W_{n} \text { is the } \mathrm{n}^{\text {th }} \text { investors wealth, } N \text { is the } \\
\text { total number of investors in the market, } X_{n} \text { is the total number of futures positions held by the } \mathrm{n}^{\text {th }} \text { investor, } C_{n} \\
\text { the total number of physical positions held by the } \mathrm{n}^{\text {th }} \text { investor, } Q_{n} \text { is the total number of other asset positions } \\
\text { (stocks) held by the } \mathrm{n}^{\text {th }} \text { investor, } F_{i} \text { is the futures price of the } \mathrm{i}^{\text {th }} \text { contract, } f_{i} \text { is the return on the } \mathrm{i}^{\text {th }} \text { futures contract, } \\
r \text { is the return on other assets (stocks), } K \text { is the total number of commodities available, } \psi \text { is he value of a } \\
\text { commodity index, } \alpha \text { is a measure of risk aversion, } H \text { for hedger, } S \text { for speculator and } I \text { for index trader. }\end{array}$} \\
\hline
\end{tabular}

Brunetti and Reiffen (2014) consider index traders, informed speculators and short hedgers, with index positions being modelled as exogenous. Traders diversify into different futures contracts of the same commodity. Their model predicts that the calendar spread is enlarged and thereby costs for short hedgers diminished by index traders rolling over their positions. 
Hamilton and $\mathrm{Wu}(2014 ; 2015)$ also consider index traders, informed speculators and short hedgers and show that index investment has the inverse effect of hedging pressure. Reminiscent of the argument made by Kaldor (1939) and Hicks (1939, pp. 146), long index traders ease hedging pressure by short hedgers as long as short hedging positions exceed long index positions. However, index traders have to pay a premium, if their long positions exceed short hedging needs. Hence, index pressure and hedging pressure alternate with the composition of traders in the market.

Akin to the hedging pressure literature, the three models assume either credit constrained or risk averse speculators so that both hedgers and index traders must pay a premium to liquidityproviding speculators. While these models successfully incorporate index traders, only Basak and Pavlova (2016) endogenously model index traders' behaviour. They draw from a market microstructure model they developed in an earlier paper for stock markets (Basak and Pavlova 2013). Their model is hence a synthesis of heding pressure and market microstructure models, while Brunetti and Reiffen (2014) and Hamilton and Wu (2014) draw on the hedging pressure literature alone.

However, the synthesis remains incomplete as one trader category referenced by the financialisation and behavioural pricing literature is omitted from all three models, uninformed and potentially trend following speculators; see Table 2. Trend following behaviour is likely in commodity markets, where information asymmetry is an inherent feature; see Cheng and Xiong (2014), Sockin and Xiong (2015), and Goldstein and Yang (2016). Hedgers have a known information advantage on inventory levels, as well as future production and consumption. Since the identity of a trader is not disclosed, a large inflow of index traders could be confused with a trade placed by an informed hedger or speculator. The prevalence of extrapolative traders may prompt arbitrageurs to close their short positions by going long, as margin calls pose increasing costs and trend-following behaviour becomes profitable. 
Another limitation of the pricing models summarised in Table 3, except for Basak and Pavlova (2016), is the neglect of the linkages between futures, spot and inventory markets. Several recent contributions by Knittel and Pindyck (2016), Kilian and Murphy (2014), Acharya et al. (2013), Ekeland et al. (2015), Sockin and Xiong (2015), Goldstein and Yang (2016) and van Huellen (2019) could potentially complement the reviewed models in Table 3. These contributions, summarised in Table 4, incorporate speculative effects in commodity futures (and spot) markets and derive implications for spot and storage markets. Although none of these studies considers index traders as a separate trader category (but uninformed or partially informed speculators instead), they provide important insights into the interplay between futures, spot and inventory markets.

Table 4. Summary of Storage Models that Account for Speculation

\begin{tabular}{|c|c|c|c|}
\hline & $\begin{array}{l}\text { Knittel and Pindyck (2016) } \\
\& \text { Kilian and Murphy (2014) }\end{array}$ & $\begin{array}{l}\text { Acharya et al. (2013) \& } \\
\text { Ekeland et al. (2015) }\end{array}$ & $\begin{array}{l}\text { Sockin and Xiong (2015) \& } \\
\text { Goldstein and Yang (2016) } \\
\& \text { van Huellen (2019) }\end{array}$ \\
\hline Assumptions & $\begin{array}{l}\text { Traders in spot and } \\
\text { inventory markets are } \\
\text { rational and have perfect } \\
\text { foresight }(\sim \mathrm{EMH}) \text {. }\end{array}$ & $\begin{array}{l}\text { Risk averse producers and } \\
\text { capital constrained } \\
\text { speculators }(\sim \text { Hedging } \\
\text { pressure models })\end{array}$ & $\begin{array}{l}\text { Information friction, } \\
\text { asymmetric information. } \\
\text { Risk averse producer } \\
\text { ( Rational herding models; } \\
\{\text { Hedging pressure models }\} \text { ) }\end{array}$ \\
\hline Trader types & $\begin{array}{l}\text { NA, no microstructure } \\
\text { provided. }\end{array}$ & $\begin{array}{l}\text { Consumer, Producer }\{\text { Storer, } \\
\text { Processor }\}, \text { Speculator }\end{array}$ & $\begin{array}{l}\text { Consumer, Storer, } \\
\text { Processor, }\{\text { Speculator }\} \text {. }\end{array}$ \\
\hline Implications & $\begin{array}{l}\text { Speculative effects through } \\
\text { storage hoarding, otherwise } \\
\text { short lived. }\end{array}$ & $\begin{array}{l}\text { Costs of hedging affects cost } \\
\text { of storage through market } \\
\text { basis, affects storage } \\
\text { decisions. }\end{array}$ & $\begin{array}{l}\text { Futures markets provide an } \\
\text { information signal resulting } \\
\text { in feedback effects from } \\
\text { futures to spot markets. The } \\
\text { effect strength depends on } \\
\text { the elasticity of arbitrage. }\end{array}$ \\
\hline
\end{tabular}

Notes: Curly brackets indicate presence in the second (or third) but not the first paper listed in the first row.

Knittel and Pindyck (2016) and Kilian and Murphy (2014) derive a structural model in which speculative influences enter in form of a premium to the futures price without further elaboration of the origin of the premium. They argue that the premium could result in an increase in spot prices via spatial arbitrage, but the increase would be short-lived unless speculative hoarding in the inventory market occurs and the price elasticity of physical demand and supply is low; the latter being a realistic assumption in the short-run due to the financial 
planning timeframe of corporations which is up to 12 months (Lagi et al. 2011). While insightful, the models by Knittel and Pindyck (2016) and Kilian and Murphy (2014) are limited in that they do not account for limits to arbitrage, information friction or different trading motives of heterogenous agents. They do not provide a microstructure for trader behaviour and appear to follow the EMH assumption of rationality and perfect foresight.

Acharya et al. (2013) combine Hirshleifer's (1988; 1990) hedging pressure model with Deaton and Laroque's (1992) optimal inventory management model. They distinguish between three different trader types in their two-period model: consumers who are only active in the spot market, risk averse producers who are active in the spot, storage and futures market and who use the futures market for hedging and speculation and capital constraint speculators who are active in the futures market. Ekeland et al. (2015) suggest a similar model but with a four-fold trader division, further distinguishing between storers and processors in the producer category to distinguish between short and long hedging demand. Both Acharya et al. (2013) and Ekeland et al. (2015) show that with increasing (short) hedging pressure, storage becomes costlier due to a stronger risk premium, resulting in a reduction of inventory holdings and therefore a lower demand in the spot market, supressing spot prices.

The two models by Acharya et al. (2013) and Ekeland et al. (2015) assume speculators to act as liquidity providers and hence price pressure originates solely from hedging demand. However, implications can be adapted for the index pressure models summarised in Table 3. As index pressure, according to Hamilton and $\mathrm{Wu}(2014 ; 2015)$ and Brunetti and Reiffen (2014), contributes to a normal market, physical traders are incentivised to store inventories as storage becomes cheaper, resulting in a higher demand at the spot market and hence a higher spot price. These considerations do not require the assumption of institutional investors buying shares of inventory firms as in Basak and Pavlova (2016) or speculative inventory hoarding as in Knittel and Pindyck (2016) and Kilian and Murphy (2014). 
Sockin and Xiong (2015) and Goldstein and Yang (2016) show that under information frictions, speculators' influence on futures prices and spot prices is not necessarily reflected in changes in inventory. Sockin and Xiong (2015) distinguish between consumers, producers and processors in their two-period model where processors hold private information about global demand and producers hold private information about supply shocks. Under these assumptions, higher prices can result in higher demand for the commodity as the information effect signalling increasing global demand outweighs the cost effect. Goldstein and Yang (2016) combine insights from Sockin and Xiong (2015) with hedging pressure models by adding financial speculators at futures markets and assuming risk averse producers and speculators. In their model, financial speculators and hedgers hold private information which enter as information signal into prices. Similar to Sockin and Xiong (2015), feedback effects between futures and spot markets can lead to pro-cyclical trading behaviour without implications for inventory holdings.

Sockin and Xiong (2015) conclude that the assumption that the 'futures price of the commodity simply tracks the spot price' must be abandoned (pp.2064). Since the two markets host different groups of market participants, the futures price is not simply a shadow of the spot price or vice versa, but dynamics in both markets and their feedback effects must be considered. Similarly, Goldstein and Yang (2016) insist that 'the futures market is not just a side show, and it has consequences for the real side' (p.11). These insights clearly distinguish these two models from the previous four in Table 4. Van Huellen (2019) builds on these insights and shows that under the assumption of information asymmetry the relationship between commodity futures and spot markets is driven by arbitrage instead of common fundamentals. If limits to arbitrage exists, the price effects of different market participants in futures and spot markets is reflected in the market basis. 
Commodity pricing models which explicitly account for index traders as a separate trader category borrow heavily from Keynesian inspired hedging pressure models. Hedging pressure models are built on the assumptions of risk averse producers and consumers and capital constraint speculators. These assumptions are carried over into the new generation of models which incorporate index pressure alongside hedging pressure. A common shortcoming of these new models is the lack of consideration of spot and storage markets; a shortcoming which has been addressed by a separate set of storage models which account for the presence of (uninformed) speculators but not yet index traders as a separate trader category. These models draw from both the hedging pressure literature and market microstructure models with the additional assumption of information frictions. A combination of both model types is promising. Interestingly, despite their Keynesian roots, none of the models considers fundamental uncertainty, which could be an interesting addition.

\section{Implications for Empirical Testing}

Drawing on the price formation models reviewed in the previous section, eight testable hypotheses regarding the effects of index traders on price discovery in commodity markets can be derived:

- H1: Index pressure results in price levels above what can be justified by market fundamentals [Level].

- H2: Index pressure results in price volatility above what can be justified by market fundamentals [Volatility].

- H3: Index pressure results in stronger co-movement of commodities that are listed in the same index than commodities that are not listed in the same index [Comovement].

- H4: Index pressure results in inflated calendar spreads [Term Structure]. 
- H5: If the market weight of index traders is substantial, the price effects in $\mathrm{H} 1-\mathrm{H} 4$ are aggravated by trend following uninformed speculators [Bubble].

- H6: Following from H4, index pressure reduces the cost of storage and therefore increases the demand for storage, resulting in higher spot prices.

- H7: In the presence of information asymmetry, spot prices adjust to futures prices via arbitrage without changes in storage.

- H8: Following from $\mathrm{H} 7$, in the additional presence of limits to arbitrage, index pressure results in a large market basis even at maturity [Basis].

These hypotheses resonate with some of the claims made early in the financialisation debate and have been tested widely. However, strategies employed by the empirical literature as well as the conclusions reached vary. This raises the questions whether empirical strategies are equally adequate for testing the above hypotheses and whether a verdict on the above hypotheses can be derived based on the existing evidence.

Empirical strategies can be differentiated into two broad categories: strategies which use trader position data in their testing and strategies which infer speculative effects from price patterns. An adequate strategy of the former type requires a method that carefully distinguishes between different trading strategies in correspondence with Table 2 and an appropriate measure of index pressure. Measures of speculative positions that aggregate over passive investors, informed and uninformed speculators are misleading in the context of the current debate. Further, a measure of index pressure must distinguish between situations where index traders act as liquidity providers and where they act as liquidity consumers since only the latter falls under the index pressure category; see Hamilton and Wu (2014; 2015) and van Huellen (2018).

The Commodity Futures Trading Commission (CFTC) provides position data differentiated by trader type for US commodity futures markets; see Irwin and Sanders (2012) and Aulerich et 
al. (2013) for a comprehensive review of the available data and its shortcomings. The major shortcoming of this data is that the classification of traders is based on industry affiliation and not trading strategy or behaviour. Further, publicly available CFTC position data aggregates over all simultaneously traded contracts and is only available in weekly frequency. These shortcomings are alleviated by a more granular non-publicly available data set in daily frequency from the CFTC large trader reporting system, which is only used by a few studies given its restricted availability. All CFTC reports cover open interest (OI) of different trader types differentiated by short, long and spread positions. Most empirical studies use net-long positions (often divided by total OI) as a measure of speculative or index positions. The measure is problematic as it does not capture index pressure which only arises if the demand for short counterparty by index traders exceeds hedgers' supply. There is hence a mismatch between the theoretical concept of index pressure and its measurement due to both shortcomings in the data and measurement construct.

Further, the claim of excessive price dynamics as in $\mathrm{H} 1$ and $\mathrm{H} 2$ is made in relation to what can be justified by market fundamentals. Testing these hypotheses empirically is challenging since fundamental factors are partly latent or data is difficult to obtain. Especially when speculative effects are inferred from price patterns, unobserved fundamental effects seriously undermine the credibility of inference from such analyses. From an empirical point of view, index pressure effects on the calendar spread or market basis in the presence of limits to arbitrage in line with $\mathrm{H} 4$ and $\mathrm{H} 8$ are better suited to test the financialisation hypothesis than effects on price levels and volatilities. This is because in the calendar spread (and market basis), fundamental factors cancel out, which alleviates some of the data problems.

However, the great majority of empirical studies that employ CFTC position data test the hypothesis of excess price levels by use of market returns [Returns]. The choice of returns is motivated by the non-stationary nature of price data preventing reliable statistical evidence to 
be obtained by use of Granger non-causality tests, the most prominently used method in the empirical literature. However, the use of returns (or first differences) instead of price levels narrows the analysis to short run dynamics which has no immediate correspondence in the theoretical literature and suffers from frequency mismatch if the publicly available weekly CFTC position data is used. An alternative empirical strategy which employs price level data instead of returns employs rolling unit root tests for detection of speculative bubbles. The strategy is also problematic as the presence of explosive growth processes in prices does not necessarily follow from the derived hypotheses and only under H5 could such scenario be plausible. Another problem is the low power of unit root tests and the sensitivity of such test to the size of the rolling window and data frequency; e.g. see Gilbert (2010).

From the above considerations it becomes clear that some empirical strategies are better suited to test the financialisation hypotheses than others. Instead of contributing yet another review of the empirical literature, I rely on five recently published reviews by Irwin and Sanders (2011), Irwin (2013), Fattouh et al. (2013), Cheng and Xiong (2014) and Boyd et al. (2018) to conduct a meta-analysis with the aim to identify fruitful empirical strategies for future research. For the analysis, I consider all papers referenced that have been published in or after 2000 in peer reviewed journals or as working papers. From an initial list of 122 individual papers, I identify those that appear twice as working paper and journal publication and disregard the working paper. If a working paper has hence been published in a peer reviewed journal, I consider the journal publication instead. I further deselect papers which do not include any statistical analysis (e.g. descriptive statistics or theoretical models only), which do not test any of the hypotheses outlined above (or variations of these hypotheses), and which do not provide any inference on commodity futures markets. The selection process identifies 58 papers covering 110 statistical tests; the full list of studies is made available as supplementary material to this paper. 
Statistical tests are differentiated by the type of hypothesis tested [Level, Basis, Bubble, Comovement, Volatility, Term Structure, Returns], the level of evidence obtained [Strong Evidence, Some Evidence, No Evidence] ${ }^{7}$, the types of commodities covered [Agriculture, Soft, Energy, Metals], the frequency of the data used [Daily, Weekly, Monthly, Quarterly, Annually], the year of publication from 2000 to 2019 [Year], whether CFTC position data is used or not [CFTC Position Data], and whether the test is published in a peer reviewed journal or in a working paper [Working Paper]. Table 5 summarises the statistical tests by the level of evidence obtained and the hypothesis tested. The top part excludes statistical tests which cover the effect of hedging pressure only. The bottom part excludes all tests that do not explicitly test for index pressure.

Table 5. Level of Evidence for Different Financialisation Hypotheses

\begin{tabular}{|c|c|c|c|c|c|c|c|c|}
\hline & & \multicolumn{2}{|c|}{ Strong Evidence } & \multicolumn{2}{|c|}{ Some Evidence } & \multicolumn{2}{|c|}{ No Evidence } & \multirow{2}{*}{$\begin{array}{r}\text { Row Total } \\
\text { Count }\end{array}$} \\
\hline & & Count & Row \% & Count & Row $\%$ & Count & Row \% & \\
\hline & & \multicolumn{7}{|c|}{ Speculative effects (including index effects) } \\
\hline \multirow{9}{*}{ 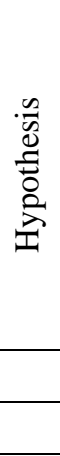 } & Level & 1 & 50.00 & 0 & 0.00 & 1 & 50.00 & 2 \\
\hline & Basis & 1 & 33.33 & 0 & 0.00 & 2 & 66.67 & 3 \\
\hline & Bubble & 2 & 25.00 & 4 & 50.00 & 2 & 25.00 & 8 \\
\hline & Comovement & 4 & 44.44 & 2 & 22.22 & 3 & 33.33 & 9 \\
\hline & Volatility & 1 & 7.69 & 3 & 23.08 & 9 & 69.23 & 13 \\
\hline & Term Structure & 7 & 46.67 & 5 & 33.33 & 3 & 20.00 & 15 \\
\hline & Returns & 16 & 30.19 & 11 & 20.75 & 26 & 49.06 & 53 \\
\hline & Total & 32 & 31.07 & 25 & 24.27 & 46 & 44.66 & 103 \\
\hline & & \multicolumn{7}{|c|}{ Index effects only } \\
\hline \multirow{8}{*}{ 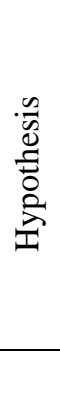 } & Level & 0 & 0.00 & 0 & 0.00 & 1 & 100.00 & 1 \\
\hline & Basis & 1 & 50.00 & 0 & 0.00 & 1 & 50.00 & 2 \\
\hline & Bubble & 1 & 20.00 & 3 & 60.00 & 1 & 20.00 & 5 \\
\hline & Comovement & 1 & 20.00 & 2 & 40.00 & 2 & 40.00 & 5 \\
\hline & Volatility & 0 & 0.00 & 1 & 16.67 & 5 & 83.33 & 6 \\
\hline & Term Structure & 5 & 45.45 & 3 & 27.27 & 3 & 27.27 & 11 \\
\hline & Returns & 7 & 25.00 & 6 & 21.43 & 15 & 53.57 & 28 \\
\hline & Total & 15 & 25.86 & 15 & 25.86 & 28 & 48.28 & 58 \\
\hline
\end{tabular}

Notes: Row \% gives the level evidence for each hypothesis tested as a percentage of total tests run for each hypothesis.

\footnotetext{
${ }^{7}$ Highly significant evidence consistent across different commodity markets is categorised as 'Strong Evidence', weakly significant evidence relative consistent across different commodity markets is categorised as 'Some Evidence', and no significant evidence and/or inconsistent and contradictory evidence across commodity markets is categorised as 'No Evidence'.
} 
As indicated previously, most of the empirical analyses conducted are with respect to commodity futures returns where the evidence remains inconclusive. Tests which target calendar spreads and market basis are few (in the case of market basis too few to make a judgment) and tend to find evidence of speculative effects more often than not. By contrast, tests which evaluate the volatility hypothesis tend to reject the hypothesis that speculators including index traders contribute to an increase in volatility. It is difficult to derive anything conclusive from the evidence provided regarding the remaining hypotheses as the number of tests is small. There seems to be some support for the co-movement and speculative bubble hypothesis.

In order to see whether other features besides the type of hypothesis tested explain the level of evidence obtained by different tests, I run a simple ordered probit model to estimate the probability of evidence being found conditional on the features extracted from the statistical tests reviewed. Let $y_{i} \in\{0,1,2\}$ be the observed outcome variable for the level of evidence corresponding to 'No Evidence', 'Some Evidence', and 'Strong Evidence' found by test $i$. Let $y_{i}^{*}$ be a latent variable representing the level of evidence found and $x_{i}$ be a vector of features or predictors for the level of evidence so that:

$$
y_{i}^{*}=x_{i}^{\prime} \beta+\varepsilon_{i}, \quad \varepsilon_{i} \sim N\left(0, \sigma^{2}\right), \forall i=1, \ldots, n
$$

Eq. (8) is linked to the observed outcome variable $y_{i}$ in the following way, with $\phi$ being the cumulative probability:

$$
\begin{array}{llc}
P\left(y_{i}=0\right)=P\left(y_{i}^{*} \leq \alpha_{0}\right) & = & \phi\left(\alpha_{0}-x_{i}^{\prime} \beta\right) \\
P\left(y_{i}=1\right)=P\left(\alpha_{0}<y_{i}^{*} \leq \alpha_{1}\right)= & \phi\left(\alpha_{1}-x_{i}^{\prime} \beta\right)-\phi\left(\alpha_{0}-x_{i}^{\prime} \beta\right) \\
P\left(y_{i}=2\right)=P\left(y_{i}^{*}>\alpha_{1}\right) & = & 1-\phi\left(\alpha_{1}-x_{i}^{\prime} \beta\right)
\end{array}
$$

I drop the intercept for identification. The vector of predictors $x_{i}$ covers the year of publication, a dummy variable which takes on one if the test is published in a working paper, the type of 
commodities considered for the test, a dummy variable that takes on one if the term structure hypothesis is tested, a dummy variable that takes on one if CFTC position data is used, and dummies for the data frequency. I exclude other hypotheses tested than the term structure hypothesis as I am interested in the comparison of hypotheses $\mathrm{H} 4$ and $\mathrm{H} 8$ to the remaining hypotheses. The number of tests on $\mathrm{H} 8$ is too small to be meaningful and hence excluded. Coefficient estimates for $\beta$ in Eq. (8) and the corresponding odds ratios are reported in Table 6. As in Table 5, the model is estimated for the larger sample $n=103$ including all studies on speculative effects and the smaller sample $n=58$ including index effects only. Robust standard errors are used throughout.

Table 6. Coefficient Estimates for $\beta$ in Eq.(8)

\begin{tabular}{|c|c|c|c|c|c|c|}
\hline & \multicolumn{3}{|c|}{$\begin{array}{c}\text { Speculative effects } \\
\text { (including index effects) }\end{array}$} & \multicolumn{3}{|c|}{ Index effects only } \\
\hline & coef. & s.e. ${ }^{\dagger}$ & odds ratio & coef. & s.e. ${ }^{\dagger}$ & odds ratio \\
\hline Year & $0.2407 * * *$ & 0.0638 & 1.27 & $0.1364 *$ & 0.0790 & 1.15 \\
\hline Working Paper & $0.8329 * *$ & 0.3404 & 2.30 & $0.7250 *$ & 0.4341 & 2.06 \\
\hline Agriculture & $-1.0629 * *$ & 0.4540 & 0.35 & $-1.4673 * *$ & 0.6304 & 0.23 \\
\hline Soft & 0.3634 & 0.3345 & 1.44 & 0.5671 & 0.3781 & 1.76 \\
\hline Energy & -0.2867 & 0.3836 & 0.75 & -0.4526 & 0.4646 & 0.64 \\
\hline Metals & $0.6985^{*}$ & 0.3903 & 2.01 & $1.5353 * * *$ & 0.5247 & 4.64 \\
\hline Term structure & $0.7421 *$ & 0.3830 & 2.10 & $0.8708 * *$ & 0.4312 & 2.39 \\
\hline CFTC Position Data & -0.1706 & 0.2659 & 0.84 & -0.0730 & 0.3830 & 0.93 \\
\hline Daily & 0.2801 & 0.4399 & 1.32 & $1.8753 *$ & 1.0431 & 6.52 \\
\hline Weekly & -0.0142 & 0.4558 & 0.99 & 1.6735 & 1.0660 & 5.33 \\
\hline Monthly & $0.8346^{*}$ & 0.4876 & 2.30 & $2.7902 * *$ & 1.2013 & 16.28 \\
\hline
\end{tabular}

Notes: ${ }^{\dagger}$ Robust standard errors. Coef. stands for coefficient estimate and s.e. stands for standard error.

* indicates significance at the 10 per cent level,

** indicates significance at the 5 per cent level,

*** indicates significance at the 1 per cent level.

From Table 6, we can infer that recent studies as well as working papers are more likely to find evidence for the financialisation hypotheses than earlier and published papers. The reasons behind this could be multiple. The development of index pressure models in recent years might have contributed to a better understanding of the implications of financialisation for price formation and thereby informed more apt empirical strategies. The fact that early empirical studies have predominantly reported no evidence for the financialisation hypotheses could have 
contributed to a publication bias so that studies that report evidence for such effect undergo more scrutiny therefore remain in the working paper stage longer. In addition to publication date and type, the type of commodity in the test matters. Tests that include agricultural commodities are less likely to find evidence for the financialisation hypotheses, while tests that include metals are more likely to find such evidence. Further, the argument that testing the financialisation hypothesis on spreads rather than price levels and volatilities is supported. Tests on the term structure hypothesis are more than twice as likely to find evidence than tests targeting other financialisation hypotheses. The effect is even stronger when limiting the sample to tests that focus exclusively on index pressure. Moreover, tests that use higher frequency data are more likely to find evidence than those using quarterly or annual data. Unfortunately, the effect of appropriate measures for index pressure on the probability of finding evidence for the financialisation hypotheses cannot be tested as none of the studies that were mentioned in the five literature reviews uses such a measure in their tests.

\section{Conclusion}

This paper provides a review of recent approaches to price formation in financialised commodity markets and the traditions from which these emerged. I show that recent approaches draw heavily on the Keynesian inspired hedging pressure literature while also borrowing from the market microstructure and rational herding literature. These new approaches to price formation incorporate index pressure effects into multi-period pricing models, but, with few exceptions, do not extent to spot and storage markets. Three types of storage models are reviewed as potential extensions for future research. In a second step, I derive testable hypotheses from the reviewed models. These hypotheses partly confirm claims made early in the financialisation debate such as excessive price levels and volatilities, an increase in co-movement of commodities of the same index, and excessive calendar spreads. 
However, a comparison between the reviewed theories and prominent empirical strategies for testing the derived hypotheses reveals several weaknesses in the empirical literature.

Conducting a meta-analysis of the existing empirical evidence, I find that some of the hypotheses derived are better suited for empirical testing than others. Hypotheses targeted at price levels and volatilities are formulated as excess price dynamics relative to what can be explained by market fundamentals. Data constraints around market fundamentals pose challenges to the empirical testing of these hypotheses. I show that a more operational approach is based on the difference between two commodity price series, as, for instance, the price series of futures contracts with different maturity dates referred to as calendar spread or term structure. Since these pairs of price series are driven by the same commodity-specific fundamentals, the difference in level and variability can be attributed to factors that are specific to the commodity price series (contract), including the different composition of traders. Further, I observe that studies that use CFTC position data fail to use adequate measures of index pressure but instead use net-long positions. This mismatch between measurement and theory might explain why tests that use position data often fail to identify hypothesised effects in the data.

\section{References}

Acharya, Viral V., Lars A. Lochstoer, and Tarun Ramadorai. 2013. "Limits to Arbitrage and Hedging: Evidence from Commodity Markets.” Journal of Financial Economics, 109 (2) 441-465.

Adam, Klaus, and Albert Marcet. 2010. "Booms and Busts in Asset Prices." London School of Economics, Centre for Economic Performance: Discussion Paper, No.1059. 
—. 2011. "Internal Rationality, Imperfect Market Knowledge and Asset Prices." Journal of Economic Theory, 146 (3) 1224-1252.

Aulerich, Nicole M., Scott H. Irwin, and Philip Garcia. 2013. "Bubbles, Food Prices, and Speculation: Evidence from the CFTC's Daily Large Trader Data Files.” NBER Working Paper Series, 19065.

Baddeley, Michelle. 2010. "Herding, Social Influences and Economic Decision-Making: Socio-Psychological and Neuroscientific Analyses." Philosophical Transactions B of The Royal Society, 365 281-290.

Banerjee, Abhijit V. 1992. "A Simple Model of Herd Behavior.” The Quarterly Journal of Economics, 107 (3) 797-817.

Barberis, Nicholas, Andrei Shleifer, and Jeffrey Wurgler. 2005. "Comovement." Journal of Financial Economics, 75 283-317.

Basak, Suleyman, and Anna Pavlova. 2013. "Asset Prices and Institutional Investors." American Economic Review, 103(5) 1728-1758.

—. 2016. "A Model of Financialization of Commodities." The Journal of Finance, 71(4) 15111556.

Basu, Parantap, and William T. Gavin. 2011. "What Explains the Growth in Commodity Derivatives?" Federal Reserve Bank of St. Louis Review, 93 (1) 37-48.

Beckert, Jens. 1996. "What is Sociological About Economic Sociology? Uncertainty and the Embeddedness of Economic Action.” Theory and Society, 25 803-840.

Bernstein, Peter L. 1999. "Why the Efficient Market Offers Hope to Active Management." Journal of Applied Corporate Finance, 12 (2) 129-136. 
Bessembinder, Hendrik. 1992. "Systematic Risk, Hedging Pressure, and Risk Premiums in Futures Markets.” The Review of Financial Studies, 5 (4) 637-667.

Bibow, Jörg, Paul Lewis, and Jochen Runde. 2005. "Uncertainty, Conventional Behaviour, and Economic Sociology.” American Journal of Economics and Sociology, 64 (2) 507-532.

Bikhchandani, Sushil, David Hirshleifer, and Ivo Welch. 1992. "A Theory of Fads, Fashion, Custom, and Cultural Change as Informational Cascades.” Journal of Political Economy, 100 (5) 992-1026.

Boyd, Naomi E., Jeffrey H. Harris, and Bingxin Li. 2018. "An update on speculation and financialization in commodity markets.” Journal of Commodity Markets, 10 91-104.

Bozic, Marin, and T. Randall Fortenbery. 2011. "Pricing Options on Commodity Futures: The Role of Weather and Storage.” Selected Paper prepared for presentation at the Agricultural \& Applied Economics Association's 2011 AAEA \& NAREA Joint Annual Meeting, Pittsburgh, Pennsylvania, July 24-26, 2011.

Brennan, Michael J. 1958. “The Supply of Storage.” The American Economic Review, 48 (1) $50-72$.

Brennan, Michael J., and Eduardo S. Schwartz. 1989. "Portfolio Insurance and Financial Market Equilibrium.” The Journal of Business, 62(4) 455-472.

Brunetti, Celso, and David Reiffen. 2014. "Commodity Index Trading and Hedging Costs." Journal of Financial Markets, 21 153-180.

Carabelli, Anna. 2002. "Speculation and Reasonableness: A Non-Bayesian Theory of Rationality.” In Keynes, Uncertainty and the Global Economy, by Sheila C. Dow and John Hillard, 165-185. Cheltenham \& Northampton Massachusetts: Edward Elgar Publishing. 
Carter, Michael. 1991. "Uncertainty, Liquidity and Speculation: A Keynesian Perspecitve on Financial Innovation in the Debt Market.” Journal of Post Keynesian Economics, 14 (2) 169-182.

Chang, Eric C. 1985. "Returns to Speculators and the Theory of Normal Backwardation." The Journal of Finance, 40(1) 193-208.

Cheng, Ing-Haw, and Wei Xiong. 2014. "The Financialization of Commodity Markets." Annual Review of Financial Economics, 6 419-41.

Davidson, Paul. 2002. Financial Markets, Money and the Real World. Cheltenham \& Massachusetts: Edward Elgar Publishing.

De Grauwe, Paul, and Marianna Grimaldi. 2006. "Exchange Rate Puzzles: A Tale of Switching Attractors." European Economic Review, 50 (1) 1-33.

De Long, J. Bradford, Andrei Shleifer, Lawrence H. Summers, and Robert J. Waldmann. 1990. “Noise Trader Risk in Financial Markets.” Journal of Political Economy, 98 (4) 703-738.

Deaton, Angus, and Guy Laroque. 1992. "On the Behaviour of Commodity Prices.” Review of Economic Studies, 59 (1) 1-23.

Devenow, Andrea, and Ivo Welch. 1996. "Rational Herding in Financial Economics." European Economic Review, 40 603-615.

Dunn, Stephen P. 2001. "Bounded Rationality is Not Fundamental Uncertainty: A Post Keynesian Perspective.” Journal of Post Keynesian Economics, 23 (4) 567-587.

Dusak, Katherine. 1973. "Futures Trading and Investor Returns: An Investigation of Commodity Market Risk Premiums.” Journal of Political Economy, 81 (6) 1387-1406. 
Ekeland, Ivar, Delphine Lautier, and Bertrand Villeneuve. 2015. "Speculation in commodity futures markets: A simple equilibrium model." Mimeo.

Erb, Claude B., and Campbell R. Harvey. 2006. "The Strategic and Tactical Value of Commodity Futures.” Financial Analysts Journal, 62 (2) 69-97.

Fama, Eugene F. 1965. “The Behavior of Stock-Market Prices.” The Journal of Business, 38 (1) 34-105.

Fama, Eugene F., and Kenneth R. French. 1987. "Commodity Futures Prices: Some Evidence on Forecast Power, Premiums, and the Theory of Storage.” The Journal of Business, 60 (1) $55-73$.

Fattouh, Bassam, Lutz Kilian, and Lavan Mahadeva. 2013. "The Role of Speculation in Oil Markets: What Have We Learned So Far?” The Energy Journal, 34 (3) 7-33.

Geman, Helyette. 2005. Commodities and Commodity Derivatives: Modelling and Pricing for Agriculturals, Metals and Energy. Chichester: John Wiley \& Sons.

Gilbert, Christopher L. 2010. "Speculative Influences on Commodity Futures Prices 20062008." UNCTAD Discussion Papers, No. 197.

Goldstein, Itay, and Liyan Yang. 2016. "Commodity Financialization: Risk Sharing and Price Discovery in Commodity Futures Markets.” Paper Presented at the 2016 American Finance Association Annual Meeting. Available at SSRN: https://ssrn.com/abstract=2555996

Gorton, Gary, and K. Geert Rouwenhorst. 2006. "Facts and Fantasies about Commodity Futures." Financial Analysts Journal, 62 (2) 47-68. 
Gouel, Christophe. 2012. “Agricultural Price Instability: A Survey of Competing Explanations and Remedies." Journal of Economic Survey, 26 (1) 129-156.

Greenwood, Robin. 2005. "A Cross Sectional Analysis of the Excess Comovement of Stock Returns.” Harvard Business School, Working Paper, No.05-069. Available at SSRN: https://ssrn.com/abstract $=698162$

Grossman, Sanford J. 1988. "An Analysis of the Implications for Stock and Futures Price Volatility of Program Trading and Dynamic Hedging Strategies.” The Journal of Business, 61(3) 275-298.

Guo, Kevin, and Tim Leung. 2017. "Understanding the Non-Convergence of Agricultural Futures via Stochastic Storage Costs and Timing Options.” Journal of Commodity Markets, $632-49$.

Hamilton, James D., and Jing Cynthia Wu. 2014. "Risk Premia in Crude Oil Futures Prices." Journal of International Money and Finance, 42 9-37.

—. 2015. "Effects of Index-Fund Investing on Commodity Futures Prices." International Economic Review 56 (1) 187-205.

Harris, Lawrence, and Eitan Gurel. 1986. "Price and Volume Effects Associated with Changes in the S\&P 500 List: New Evidence for the Existence of Price Pressure.” The Journal of Finance, 41 (4) 815-829.

Hayes, Mark G. 2006. "Value and Probability.” Journal of Post Keynesian Economics, 28(3) $527-538$.

Henderson, Brian J., Neil D. Pearson, and Li Wang. 2015. "New Evidence on the Financialization of Commodity Markets.” Review of Financial Studies, 28 (5) 1285-1311. 
Hicks, John. 1939. Value and Capital. Cambridge: Oxford University Press.

Hirshleifer, David. 1988. "Residual Risk, Trading Costs, and Commodity Futures Risk Premia." The Review of Financial Studies, 1 (2) 173-193.

—. 1990. "Hedging Pressure and Futures Price Movements in a General Equilibrium Model." Econometrica, 58 (2) 411-428.

Irwin, Scott H. 2013. "Commodity Index Investment and Food Prices: Does the "Masters Hypothesis" Explain Recent Price Spikes?” Agricultural Economics, 44 (supplement) 2941.

Irwin, Scott H., and Dwight R. Sanders. 2011. "Index Funds, Financialization, and Commodity Futures Markets.” Applied Economic Perspectives and Policy, 33 (1) 1-31.

—. 2012. "Testing the Masters Hypothesis in commodity futures markets." Energy Economics, $34256-269$.

Jeanne, Oliver. 2000. "Currency Crises: A Perspective on Recent Theoretical Developments." Princeton University, Department of Economics, Special Papers in International Economics, 20.

Kaldor, Nicholas. 1939. "Speculation and Economic Stability." The Review of Economic Studies, 7 (1) 1-27.

Keynes, John Maynard. 1930. A Treaties on Money, Vol. II, Book VI, Ch. 29. London: Macmillan Cambridge University Press.

Kilian, Lutz, and Daniel P. Murphy. 2014. "The Role of Inventories and Speculative Trading in the Global Market for Crude Oil.” Journal of Applied Econometrics, 29 454-478. 
Knittel, Christopher R., and Robert S. Pindyck. 2016. "The Simple Economics of Commodity Price Speculation.” American Economic Journal: Macroeconomics, 8 (2) 85-110.

Krugman, Paul R. 1979. “A Model of Balance-of-Payment Crises.” Journal of Money, Credit and Banking, 11 311-325.

Lagi, Marco, Yavni Bar-Yam, Karla Z. Bertrand, and Yaneer Bar-Yam. 2011. "The Food Crises: A Quantitative Model of Food Prices Including Speculators and Ethanol Conversion.” Available at SSRN: https://ssrn.com/abstract=1932247

Lautier, Delphine. 2005. “Term Structure Models of Commodity Prices: A Review.” Journal of Alternative Investments, 8 (1) 42-64.

Lawson, Tony. 1985. "Uncertainty and Economic Analysis.” The Economic Journal, 95 (380) 909-927.

Lo, Andrew W. 2012. "Perspectives: Adaptive Markets and the New World Order." Financial Analysts Journal, 68 (2) 18-29.

Masters, Michael W. 2008. "Testimony of Michael W. Masters before the Committee on Homeland Security and Governmental Affairs United States Senate, May 20, 2008.”

Mayer, Jörg. 2012. "The Growing Financialisation of Commodity Markets: Divergences between Index Investors and Money Managers.” Journal of Development Studies, 48 (6) $751-67$.

McAleer, Michael, and Kim Radalj. 2013. "Herding, Information Cascades and Volatility Spillovers in Futures Markets." Journal of Reviews on Global Economics, 2 307-329. 
Nissanke, Machiko. 2012. "Commodity Market Linkages in the Global Financial Crisis: Excess Volatility and Development Impacts.” The Journal of Development Studies, 48 (6) $732-750$.

Obstfeld, Maurice. 1986. "Rational and Self-Fulfilling Balance-of-Payment Crises." American Economic Review, 76(1) 72-81.

O'Hara, Maureen. 1997. Market Microstructure Theory. Oxford: Blackwell Publishers Ltd.

Pindyck, Robert S. 2001. "The Dynamics of Commodity Spot and Futures Markets: A Primer." The Energy Journal, 22 (3) 1-29.

Pirrong, Craig. 2011. "Stochastic Fundamental Volatility, Speculation, and Commodity Storage.” In Commodity Price Dynamics: A Structural Approach, by Craig Pirrong, 109130. Cambridge, UK: Cambridge University Press.

Rosser Jr., J. Barkley. 2001. "Alternative Keynesian and Post Keynesian Perspectives on Uncertainty and Expectations." Journal of Post Keynesian Economics, 23 (4) 545-566.

Scharfstein, David S., and Jeremy C. Stein. 1990. "Herd Behavior and Investment." The American Economic Review, 80 (3) 465-479.

Shleifer, Andrei. 1986. "Do Demand Curves for Stocks Slope Down?” The Journal of Finance, 41(3) 579-590.

—. 2000. Inefficient Markets: An Introduction to Behavioural Finance. Oxford: Oxford University Press.

Shleifer, Andrei, and Lawrence H. Summers. 1990. "The Noise Trader Approach to Finance.” The Journal of Economic Perspectives, 4 (2) 19-33. 
Shleifer, Andrei, and Robert W. Vishny. 1997. "The Limits of Arbitrage." The Journal of Finance, 52 (1) 35-55.

Simon, Herbert A. 1955. “A Behavioural Model of Rational Choice.” The Quarterly Journal of Economics, 69 (1) 99-118.

Singleton, Kenneth J. 2014. "Investor Flows and the 2008 Boom/Bust in Oil Prices." Management Science, 60 (2) 300-318.

Sockin, Michael, and Wei Xiong. 2015. "Informational Frictions and Commodity Markets." The Journal of Finance, 70 (5) 2063-98.

van Huellen, Sophie. 2018. "How Financial Investment Distorts Food Prices: Evidence from US Grain Markets.” Agricultural Economics, 49 (2) 171-181.

van Huellen, Sophie. 2019. "Price Discovery in Commodity Futures and Cash Markets with Heterogeneous Agents.” Journal of International Money and Finance, 95 1-13.

Welch, Ivo. 1992. "Sequential Sales, Learning, and Cascades.” The Journal of Finance, 47 (2) 695-732.

Working, Holbrook. 1949. "The Theory of Price and Storage." The American Economic Review, 39 (6) 1254-1262.

—. 1960. "Speculation on Hedging Markets.” Food Research Institute Studies, 1 (2) 1-36. 